
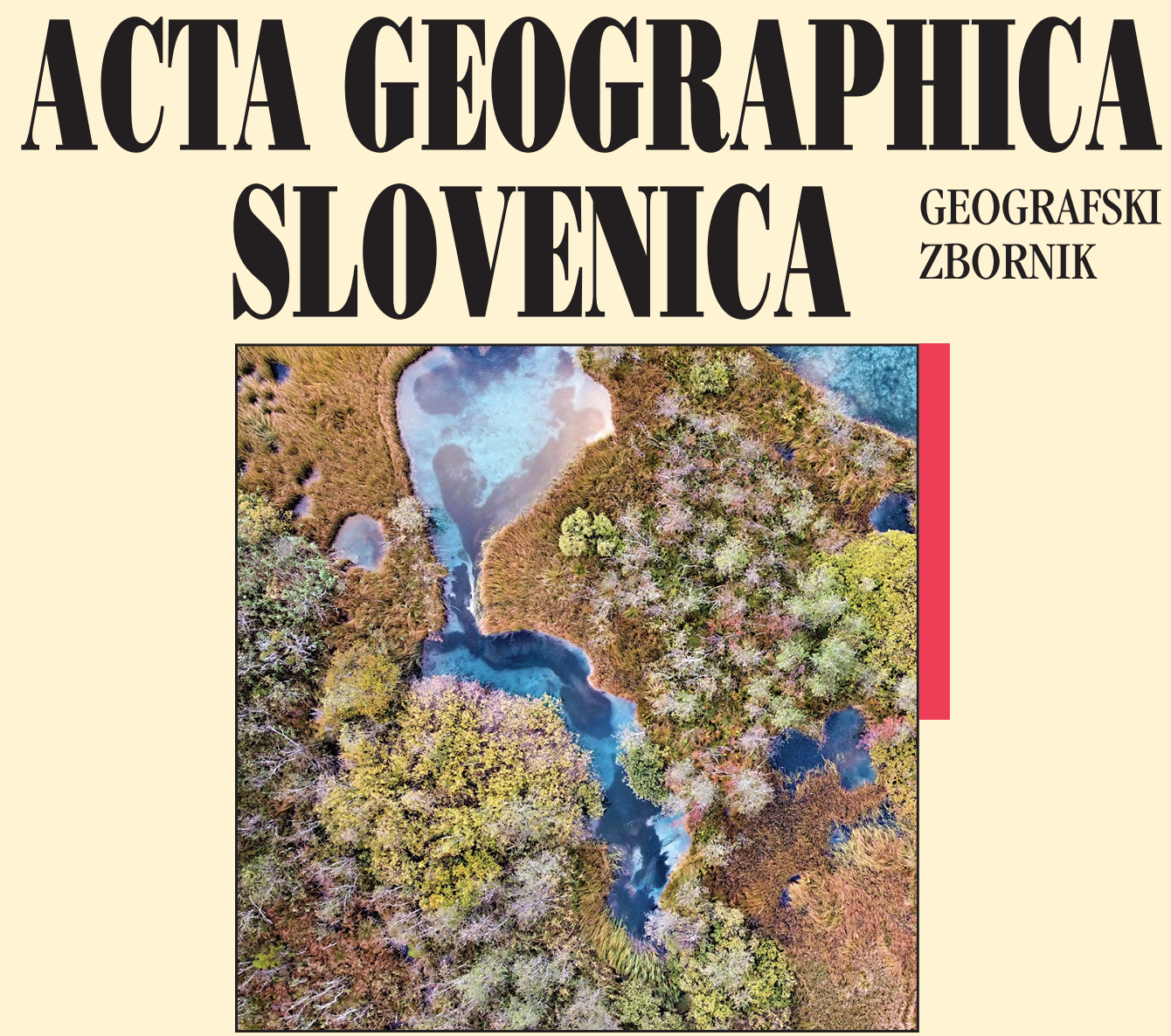


\section{ACTA GEOGRAPHICA SLOVENICA GEOGRAFSKI ZBORNIK 61-2 • 2021}

\section{Contents}

Đorđije VASILJEVIĆ, Milica BEGAN, Miroslav VUJIČIĆ, Thomas HOSE, Uglješa STANKOV

Does geosite interpretation lead to conservation? A case study of the Sićevo Gorge (Serbia)

Gabrijela POPOVIĆ, Dragiša STANUJKIĆ, Predrag MIMOVIĆ, Goran MILOVANOVIĆ, Darjan KARABAŠEVIĆ, Pavle BRZAKOVIĆ, Aleksandar BRZAKOVIĆ

An integrated SWOT - extended PIPRECIA model for identifying key determinants of tourism development: The case of Serbia

Robert KALBARCZYK, Eliza KALBARCZYK

Precipitation variability, trends and regions in Poland: Temporal and spatial distribution in the years 1951-2018

Ivana CRLJENKO, Matjaž GERŠIČ

A comparison of the beginnings of exonym standardization in Croatian and Slovenian

Tadej BREZINA, Jernej TIRAN, Matej OGRIN, Barbara LAA

COVID-19 impact on daily mobility in Slovenia

Maruša GOLUŽA, Maruška ŠUBIC-KOVAČ, Drago KOS, David BOLE

How the state legitimizes national development projects: The Third Development Axis case study, Slovenia

Tin LUKIĆ, Tanja MICIĆ PONJIGER, Biljana BASARIN, Dušan SAKULSKI, Milivoj GAVRILOV, Slobodan MARKOVIĆ, Matija ZORN, Blaž KOMAC, Miško MILANOVIĆ, Dragoslav PAVIĆ, Minučer MESAROŠ, Nemanja MARKOVIĆ, Uroš DURLEVIĆ, Cezar MORAR, Aleksandar PETROVIĆ Application of Angot precipitation index in the assessment of rainfall erosivity: Vojvodina Region case study (North Serbia)

Janij OBLAK, Mira KOBOLD, Mojca ŠRAJ

The influence of climate change on discharge fluctuations in Slovenian rivers

Vladimir STOJANOVIĆ, Dubravka MILIĆ, Sanja OBRADOVIĆ, Jovana VANOVAC, Dimitrije RADIŠIĆ

The role of ecotourism in community development: The case of the Zasavica Special Nature Reserve, Serbia

Marko V. MILOŠEVIĆ, Dragoljub ŠTRBAC, Jelena ĆALIĆ, Milan RADOVANOVIĆ Detection of earthflow dynamics using medium-resolution digital terrain models: Diachronic perspective of the Jovac earthflow, Southern Serbia

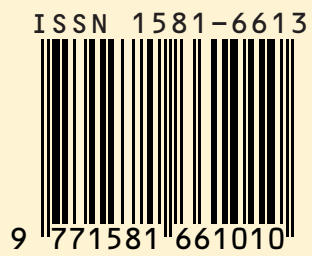




\section{AN INTEGRATED SWOT - EXTENDED PIPRECIA MODEL FOR IDENTIFYING KEY DETERMINANTS OF TOURISM DEVELOPMENT: THE CASE OF SERBIA}

Gabrijela Popović, Dragiša Stanujkić, Predrag Mimović, Goran Milovanović, Darjan Karabašević, Pavle Brzaković, Aleksandar Brzaković

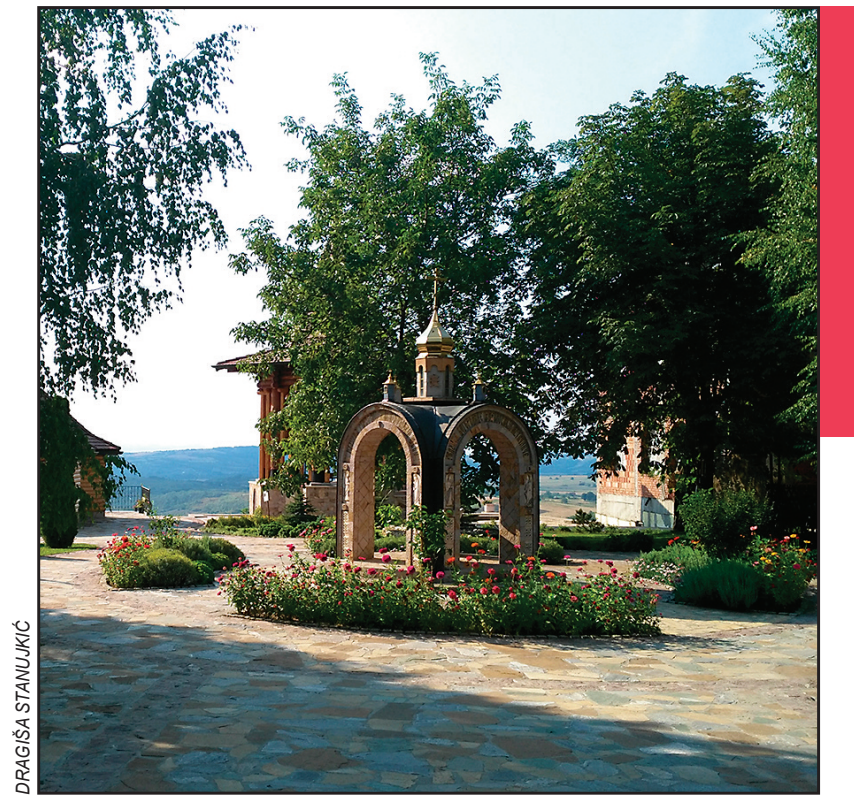

Lešje Monastery near Paraćin, Serbia. 
DOI: https://doi.org/10.3986/AGS.9271

UDC: $338.486: 004.652(497.11)$

COBISS: 1.01

Gabrijela Popović ${ }^{1}$, Dragiša Stanujkić ${ }^{2}$, Predrag Mimović ${ }^{3}$, Goran Milovanović ${ }^{4}$, Darjan Karabašević ${ }^{1}$, Pavle Brzaković ${ }^{1}$, Aleksandar Brzaković ${ }^{1}$

\title{
An integrated SWOT - extended PIPRECIA model for identifying key determinants of tourism development: The case of Serbia
}

\begin{abstract}
This paper proposes a new integrated model based on SWOT and extended PIvot Pairwise RElative Criteria Importance Assessment (PIPRECIA) that offers a systematic approach to strategic planning in tourism. The applicability of the proposed integrated model is demonstrated through a case study defining the main determinants of tourism development in Serbia. The result emphasizes the strategy Improving the organization, management, and enhancement of tourism development as the highest priority for implementation. The model facilitates decision-making in tourism, and its key advantages are its suitability for application in group decision-making and its simplicity.
\end{abstract}

KEY WORDS: extended PIPRECIA method, SWOT, Serbia, strategy, tourism

\section{Integrirani model za določanje ključnih determinant turističnega razvoja, ki temelji na analizi SWOT in razširjeni metodi PIPRECIA: primer Srbije}

POVZETEK: V članku avtorji predlagajo nov integrirani model, ki temelji na analizi SWOT in razširjeni metodi PIPRECIA (PIvot Pairwise RElative Criteria Importance Assessment) ter omogoča sistematičen pristop $\mathrm{k}$ strateškemu načrtovanju v turizmu. Uporabnost predlaganega modela je predstavljena s študijo primera, v kateri avtorji določijo glavne determinante turističnega razvoja v Srbiji. Izsledki kažejo, da je med različnimi strategijami najpomembnejša tista, ki se osredotoča na izboljšanje organizacije, upravljanja in krepitve turističnega razvoja. Model omogoča lažje odločanje v turizmu, njegova ključna prednost pa je ta, da je primeren za skupinsko odločanje in preprost za uporabo.

KLJUČNE BESEDE: razširjena metoda PIPRECIA, analiza SWOT, Srbija, strategija, turizem

This paper was submitted for publication on November $10^{\text {th }}, 2020$.

Uredništvo je prejelo prispevek 10. novembra 2020.

\footnotetext{
${ }^{1}$ University Business Academy in Novi Sad, Faculty of Applied Management, Economics and Finance in Belgrade, Belgrade, Serbia gabrijela.popovic@mef.edu.rs (https://orcid.org/0000-0002-2652-4860), darjan.karabasevic@mef.edu.rs (https://orcid.org/0000-0001-5308-2503), pavle.brzakovic@mef.edu.rs (https://orcid.org/0000-00015184-9627), aleksandar.brzakovic@mef.edu.rs

${ }^{2}$ University of Belgrade, Technical Faculty in Bor, Bor, Serbia dstanujkic@tfbor.bg.ac.rs (https://orcid.org/0000-0002-6846-3074)

${ }^{3}$ University of Kragujevac, Faculty of Economics, Kragujevac, Serbia mimovicp@kg.ac.rs (https://orcid.org/0000-0003-0323-8033)

${ }^{4}$ University of Niš, Faculty of Economics, Niš, Serbia goran.milovanovic@eknfak.ni.ac.rs (https://orcid.org/0000-0003-0091-2774)
} 


\section{Introduction}

Serbia is a landlocked Balkan country. Despite not having sea access, it has significant potential for developing and enhancing various kinds of tourism. Today, the development potential of rural tourism in Serbia has attracted the most attention among researchers (Todorović and Bjeljac 2009; Dimitrovski, Todorović and Valjarević 2012; Petrović et al. 2018). Apart from rural tourism, other types of tourism suitable for development have also been studied (Košić et al. 2011; Vasiljević et al. 2011; Vujičić et al. 2011; Dragićević et al. 2012; Dragičević et al. 2013; Blešić et al. 2014; Vujko and Plavša 2014; Božić and Tomić 2016; Pavluković, Stankov and Arsenović 2020). Mulec and Wise (2013) and Armenski, Dwyer and Pavluković (2018) have also examined the competitiveness of the Vojvodina region and Serbia as a whole as tourism destinations.

Improving tourism in Serbia requires determining its positive and negative aspects, which could drive or hinder further development. In addition to other data on tourism and predictions for the future, the Tourism Development Strategy of the Republic of Serbia 2016-2025 (2016) also contains a SWOT (strengths, weaknesses, opportunities, and threats) analysis. It clearly outlines the internal and external factors important for further tourism development, as well as strategies to take advantage of strengths and opportunities, avoid threats, and overcome weaknesses. Despite its benefits, the qualitative nature of SWOT analysis is a shortcoming. This can be overcome by combining SWOT analysis with appropriate multiple-criteria decision-making (MCDM) methods.

This article proposes applying the SWOT - extended PIvot Pairwise RElative Criteria Importance Assessment framework, or PIPRECIA (Stanujkic et al. 2017a). PIPRECIA is a newly developed MCDM method that is convenient for application in a group decision environment. The paper proposes the SWOT extended PIPRECIA integrated model as a convenient tool for strategic planning in tourism. The applicability of the model is presented through a case study based on tourism development data from the Tourism Development Strategy of the Republic of Serbia 2016-2025 (2016). This model determines the key SWOT influential factors, and it prioritizes strategies to improve tourism in Serbia. The paper proposes a new model based on SWOT and the relatively recently introduced MCDM method, whose possibilities in strategic planning have not been tested yet.

\section{Literature review}

SWOT analysis is widely used in tourism to appraise internal (strengths and weaknesses) and external (opportunities and threats) factors important for assessing the market position of certain destinations, and it is the first phase in strategic planning and creating a strategy. The applicability of this technique has been shown in various studies (Abdi and Azadegan-Mehr 2011; Sariisik, Turkay and Akova 2011; Ghazinoory, Reihanian et al. 2012; Cetin 2015; Gürel and Tat 2017; Cetin et al. 2018). Although SWOT analysis is the starting point in strategic planning, it is sometimes criticized for leading to the creation of unsuitable strategies (Hill and Westbrook 1997; Kurttila et al. 2000; Helms and Nixon 2010; Vlados 2019). Such criticism mainly addresses its qualitative nature, inability to express factors quantitatively, and inability to determine which factor has a decisive impact (Kajanus et al. 2012). These shortcomings can be resolved by applying MCDM methods.

MCDM methods have become increasingly popular in recent decades, having been applied in many different research areas (Zavadskas and Turskis 2011; Gavade 2014; Zavadskas, Turskis and Kildienè 2014; Stojčić et al. 2019). They are especially convenient for application in situations where a greater number of criteria are included, against which the decision-maker (DM) should perform the evaluation process and make the final decision (Stanujkic et al. 2017b; Stanujkic et al. 2017c; Popovic, Stanujkic and Karabasevic 2019). These techniques are useful in facilitating decisions and increasing the reliability of decisions. In addition to resolving various business problems, MCDM methods are also used to facilitate decisions in tourism with regard to policy (Liu, Tzeng and Lee 2012; Michailidou, Vlachokostas and Moussiopoulos 2016), competitiveness (Wu 2011; Zhang et al. 2011; Huang and Peng 2012; Gómez-Vega and Picazo-Tadeo 2019), sustainable tourism and ecotourism (Michalena, Hills and Amat 2009; Aliani et al. 2017; Arsić, Nikolić and Živković 2017), location and destination selection (Chou, Hsu and Chen 2008; Cheng, Su and Tan 2013; Morteza et al. 2016; Aksoy and Ozbuk 2017; Puška, Stojanović and Maksimović 2019), service quality 
(Rozman et al. 2009; Tseng 2011; Zoraghi et al. 2013; Wu and Wang 2014), and website quality (Hu 2009; Akincilar and Dagdeviren 2014; Stanujkic, Zavadskas and Tamošaitienė 2015; Stanujkic et al. 2017b).

Combining one of these methods with SWOT analysis creates a hybrid model, preserving the benefits of SWOT analysis and eliminating the shortcomings explained above. The most popular and most frequently used hybrid model is the A'WOT model, based on combining SWOT analysis and the Analytic Hierarchy Process or AHP method (Saaty 1980). This model is often applied in strategic planning in tourism (Kajanus, Kangas and Kurttila 2004; Mimović, Kocić and Milanović 2012; Akbulak and Cengiz 2014; Nikolić et al. 2015; Demir, Esbah and Akgün 2016). In addition to the A'WOT model, other combinations of the MCDM methods and SWOT analysis have also been proposed as a decision-making aid in tourism (Arsić, Nikolić and Živković 2017; Ajmera 2017; Abadi et al. 2018; Khan 2018; Popović, Milovanović and Stanujkić 2018; Jiskani et al. 2020).

The extended PIPRECIA method is an improved version of the Step-Wise Weight Assessment Ratio Analysis or SWARA method (Keršuliene et al. 2010). It retains the benefits of the SWARA method and ameliorates its shortcomings. The SWARA method is not suitable for group decision-making environments, which may be its crucial disadvantage. This unsuitability arises from the fact that every DM should sort criteria according to their significance, which complicates obtaining the results from all DMs. The possibility that each DM could sort criteria in a different order makes evaluation more complex. Furthermore, the SWARA method does not anticipate consistency checking, and so the reliability of the results obtained is somewhat questionable.

Group decision-making requires a method that facilitates the process and is easy to apply. Extended PIPRECIA almost entirely meets these requirements. Namely, extended PIPRECIA does not require presorting of criteria. This method therefore automatically becomes more suitable for group decision-making. Then, the evaluation procedure is more straightforward than in the AHP method (Saaty 1980). The AHP method requires a more detailed explanation than extended PIPRECIA for DMs involved if they are unfamiliar with it. The AHP and extended PIPRECIA methods are similar in requiring consistency checking. For this purpose, consistency checking in extended PIPRECIA is conducted by using Pearson's or Spearman's correlation and by applying the bidirectional approach; that is, top-down and bottom-up evaluation of criteria. This bidirectional approach in consistency testing could be complicated for DMs because they have to change their way of thinking while evaluating criteria from both sides. It requires an analytic approach and measuring the importance that one particular criterion has in relation to the previous and next criterion (depending on the side the evaluation starts from). This manner of estimating criteria significance, however, contributes to the reliability of the results and the ranking order.

Extended PIPRECIA was used to facilitate decision-making in several areas. Plain PIPRECIA, which is an integral part of extended PIPRECIA, is very convenient for criteria weight determination (e.g., Karabasevic et al. 2019). Extended PIPRECIA was proposed for evaluating the quality of websites (Stanujkic, Karabasevic and Sava 2018) and for assessing consumer satisfaction with restaurant service (Stanujkic et al. 2019). Stević et al. (2018) also introduced a fuzzy extension of the PIPRECIA method that is also used in the decision process (Đalić et al. 2020a; Đalić et al. 2020b; Memiş et al. 2020; Vesković 2020). Extended PIPRECIA is applied for selecting an adequate mining method (Popović, Đorđević and Milanović 2019). In tourism, extended PIPRECIA is used to prioritize projects for developing accommodation facilities (Popović and Mihajlović 2018) and for ranking sustainable indicators for cultural heritage sites (Popovic et al. 2019).

This indicates that there is enough room to further examine and test the possibilities of extended PIPRECIA. Moreover, no examples of a combination of SWOT analysis and extended PIPRECIA have been found in tourism.

\section{Methodology}

Developing the integrated model is performed in two phases. The first phase involves preliminary evaluation of the SWOT factors using the PIPRECIA method, determining the five most important ones from each group, and defining the appropriate strategies. The main reason for selecting five is to avoid an excessive example that would exacerbate the understanding of the proposed approach. The second phase develops and applies the extended model based on the SWOT technique and extended PIPRECIA. Figure 1 shows the guiding concept of building the integrated SWOT - extended PIPRECIA model. The crucial benefits and main shortcomings of both techniques are examined below. 


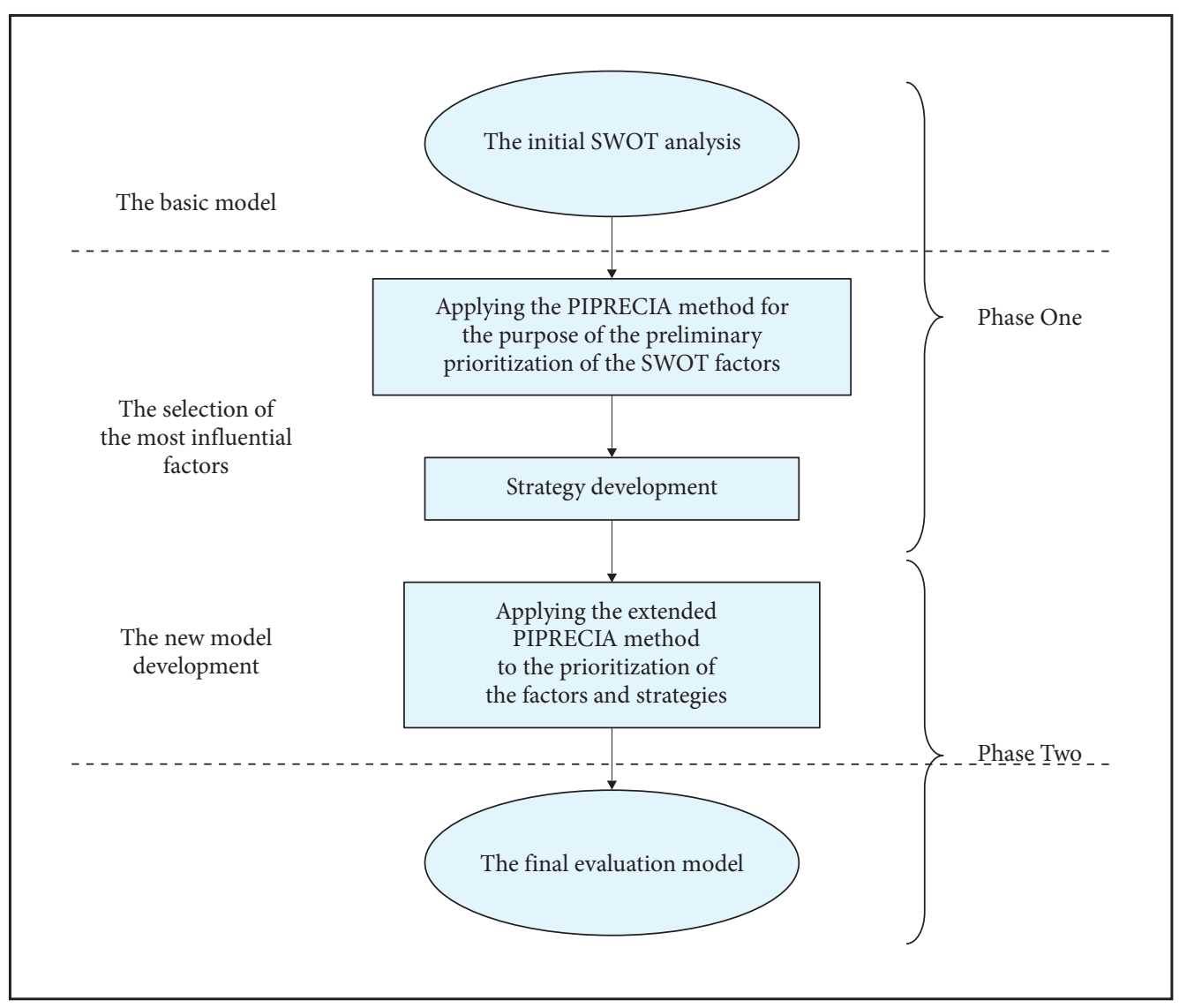

Figure 1: The proposed methodology.

\subsection{SWOT analysis}

SWOT analysis gained popularity because it makes it possible to simultaneously scan internal strengths and weaknesses and external opportunities and threats for proper diagnosis of a current state to develop an appropriate strategy.

Although SWOT analysis could be considered an inevitable technique for screening a business situation and determining convenient strategies, some consider it to have certain flaws (Kurttila et al. 2000; Yüksel and Dagdeviren 2007; Kajanus et al. 2012).

In the present case, a SWOT analysis was used in the first phase to evaluate opportunities for tourism development in Serbia. The SWOT analysis is very extensive and contains many SWOT factors. To avoid complexity, the evaluation is divided into two phases. In the first phase, the five most influential factors from each group are determined based on the complete list of SWOT factors. A questionnaire was distributed to six private hotel managers and eight tourist board managers for selected municipalities. Complete data for further processing were obtained from five DMs (three tourist board managers and two hotel managers), which showed how the model can be used in a group decision environment. The significance of all SWOT factors was determined by applying the PIPRECIA method. In this phase, DMs defined the strategies that best meet the advantages and disadvantages of tourism development in Serbia. The five most influential factors from each group and proposed strategies were the entry data for phase two. 


\subsection{Extended PIPRECIA}

Extended PIPRECIA (Stanujkic et al. 2017a), which includes the PIPRECIA and inverse PIPRECIA methods, was used in the second phase of evaluating opportunities for tourism development in Serbia. The five DMs assessed the given factors and strategies individually by using extended PIPRECIA. The overall significance of the factors and strategies were then determined and, by multiplying the results obtained, the importance of degrees of strategies were determined. The computational procedure, based on Stanujkic et al. (2017a), is presented below.

Step 1. Select the criteria for evaluation. In this case, the criteria are SWOT factors and strategies.

Step 2. Determine the relative significance $s_{j}$ starting from the second criterion in the following manner:

$$
s_{j}=\left\{\begin{array}{ccc}
>1 & \text { when } & C_{j} \succ C_{j-1} \\
1 & \text { when } & C_{j}=C_{j-1} \\
<1 & \text { when } & C_{j} \prec C_{j-1}
\end{array}\right\},
$$

where $s_{j}$ denotes the significance of criterion $j, C_{j}$ denotes the importance of criterion $j$, and $C_{j-1}$ denotes the importance of the previous criterion.

This means that $s_{j}$ has values greater than 1 when $C_{j}$ dominates a previous criterion $C_{j-1}$; that is, when it is more important than the previous criterion, whereby a higher value of $s_{j}$ means a higher level of dominance and $s_{i}=(1,1.8]$. Similarly, $s_{j}$ has a value less than 1 when the criterion $C_{j}$ is dominated by $C_{j-1}$ and then $s_{i}=(1,0.2]$. Finally, $s_{j}$ has a value of 1 when both criteria are of the same importance.

Step 3. Calculate the adjusted significance $k_{j}$ as follows:

$$
k_{j}=\left\{\begin{array}{cc}
1 & j=1 \\
2-s_{j} & j>1
\end{array}\right\} .
$$

where $k_{j}$ denotes the adjusted significance of criterion $j$.

Step 4. Define the relative adjusted significance $q_{\mathrm{j}}$ by using Eq. (3):

$$
q_{j}=\left\{\begin{array}{cc}
1 & j=1 \\
\frac{q_{j-1}}{k_{j}} & j>1
\end{array}\right\} .
$$

where $q_{j}$ denotes the relative adjusted significance of criterion $j$.

Step 5. Determine the relative weights $w$ of the estimated criteria $j$ in the following manner:

$$
w_{j}=\frac{q_{j}}{\sum_{k=1}^{n} q_{k}},
$$

where $w_{j}$ denotes the relative weight of criterion $j$.

Step 6. Compute the inverse relative significance $s_{j}^{\prime}$ starting from the penultimate criterion as follows:

$$
s_{j}^{\prime}=\left\{\begin{array}{ccc}
>1 & \text { when } \quad c_{j}>c_{j+1} \\
1 & \text { when } \quad c_{j}=c_{j+1} . \\
<1 & \text { when } \quad c_{j}<c_{j+1}
\end{array}\right.
$$


Step 7. Define the inverse adjusted significance $k_{j}^{\prime}$ in the following manner:

$$
k_{j}^{\prime}=\left\{\begin{array}{cc}
1 & j=n \\
2-s_{j}^{\prime} & j<1
\end{array} .\right.
$$

Step 8. Determine the inverse relative adjusted significance $q_{j}^{\prime}$ by using the following equation:

$$
q_{j}^{\prime}=\left\{\begin{array}{cc}
1 & j=n \\
\frac{q_{j+1}^{\prime}}{k_{j}^{\prime}} & j<n
\end{array} .\right.
$$

Step 9. Detect the inverse relative weights of the evaluated criteria as follows:

$$
w_{j}^{\prime}=\frac{q_{j}^{\prime}}{\sum_{k=1}^{n} q_{k}^{\prime}}
$$

where $w_{j}^{\prime}$ denotes the inverse weight of criterion $j$.

Step 10. Confirm the reliability of the results obtained by using Spearman's rank correlation coefficient:

$$
\rho=1-\frac{6 \sum_{i=1}^{n} d_{j}^{2}}{n\left(n^{2}-1\right)},
$$

where denotes the correlation coefficient, $d_{j}$ denotes the distance between the ranks of $w_{j}$ and $w_{j}^{\prime}, n$ is the number of criteria, and $\rho \in=(-1,1]$.

Step 11. The total weight of the criteria is computed by applying the following equation:

$$
w_{j}^{\prime \prime}=\frac{1}{2}\left(w_{j}+w_{j}^{\prime}\right)
$$

where $w_{j}^{\prime \prime}$ denotes the complete weight of criterion $j$.

Step 12. When the decision process is performed in a group environment, then the final weights of the criteria are obtained in the following manner:

$$
\begin{gathered}
w_{j}^{*}=\left(\prod_{r=1}^{R} w_{j}^{n r}\right)^{1 / R}, \\
w_{j}=\frac{w_{j}^{*}}{\sum_{j=1}^{n} w_{j}^{*}},
\end{gathered}
$$

where $w_{j}^{n r}$ denotes the weight of criterion $j$ obtained from respondent $r, R$ is the number of the respondents, $w_{j}^{*}$ is the group weight of criterion $j$ before adjustment to fulfill the condition $\sum_{j=1}^{n} w_{j}=1$, and $w_{j}$ is the final group weight of criterion $j$. 
G. Popović, D. Stanujkić, P. Mimović, G. Milovanović, D. Karabašević, P. Brzaković, A. Brzaković, An integrated SWOT ...

\section{Results}

This section presents the results of the evaluation procedure. In using the proposed framework, the most influential SWOT factors are determined and strategies that will lead to a better position for Serbia on the global tourism market are emphasized.

\subsection{Preliminary evaluation: phase one}

This preliminary evaluation is performed by using the plain PIPRECIA method, which is part of extended PIPRECIA. The computational procedure is performed by using equations (1)-(4) and equations (11)-(12). The results obtained, as well as the proposed strategies, are presented in Table 1.

Table 1: SWOT matrix for developing tourism in Serbia (Tourism Development Strategy 2016).

Internal factors

Strengths (S)

$S_{1}$ - Various resources and the tourist attraction structure in Serbia as the basis for developing a diversified tourist product portfolio.

$S_{2}-$ A modern legal framework for planning tourism destinations.

$S_{3}-A$ continuous trend of increasing overnight stays by foreign tourists in Serbia, primarily in Belgrade.

$\mathrm{S}_{4}$ - Internationally positioned and professionally organized events that raise tourists' awareness of Serbia as a tourism destination.

$S_{5}$ - Several airfields that could become usable for low-budget air companies by making a small investment.
Weaknesses $(W)$

$W_{1}$ - Disrespect for environmental protection measures in protected natural areas, neglecting structures and monuments under state protection, numerous examples of squalor, environment pollution, and space degradation, and insufficient coordination of tourism development and environment protection.

$W_{2}-$ A low budget for promoting tourism in Serbia.

$W_{3}^{2}$ - Enterprises operating in tourism and hospitality are insufficiently informed about EU funds and do not make use of them.

$W_{4}$ - The inadequate domestic internet platform and information and communications technology (ICT) applications for promoting tourist attractions, virtual guides, and presentations.

$W_{5}$ - Serbia's competition further lagging behind and losing a potential market.

External factors

Opportunities (0)

$0_{1}$ - Serbia's foreign policy: abolishing visas and visa facilitation for some countries; facilitating visa issuance at the border (for Turkey and China).

$\mathrm{O}_{2}-$ Changing habits and tourist motivations on the global market and seeking new experiences, attractions, and products, and a preserved environment.

$\mathrm{O}_{3}$ - Using resources for social programs for the staff surplus in public administration for work reintegration in tourism.

$\mathrm{O}_{4}$ - Dynamic growth and development of air transport and reaching new destinations.

$\mathrm{O}_{5}$ - Strengthening regional cooperation and creating regional tourism products for better positioning of tourism and attracting tourists from distant overseas markets.
Threats $(T)$

$T_{1}-$ Political tensions in the Balkans.

$T_{2}$ - Losing the opportunity to use government reforms and abandoning the longstanding policy of exclusively supporting public institutions.

$T_{3}$ - Abandoning the sale or licensing of every unprofitable property whose owner is Serbia or public enterprises in tourism, which could be used for supporting current or new small and medium-sized enterprises.

$T_{4}$ - Lack of management and coordination reforms in developing tourism in Serbia.

$T_{5}$ - Disconnected and uncoordinated activity in implementing the Strategy and Action Plan for the Implementation of the Tourism Development Strategy of the Republic of Serbia 2016-2025.

Strategies

SO strategy

$\mathrm{SO}_{1}$ - Improving tourist and traffic infrastructure in Serbia.

$\mathrm{SO}_{2}$ - Improving tourist products and services in Serbia.
ST strategy

$S T_{1}$ - Improving the organization, management, and enhancement of tourism development.
WO strategy

WO - Improving human resources and the labor market.
WT strategy

$W T_{1}$ - Networking with other sectors.

$W T_{2}$ - Improving the national tourism marketing system. 
After defining the most influential factors and forming strategies, the final evaluation procedure with extended PIPRECIA is performed in phase two.

\subsection{Final evaluation: phase two}

Table 2 shows the priorities for each SWOT group computed by applying Eqs. (1)-(12). The reliability of the responses is checked with Spearman's coefficient and, based on the results, the DMs' responses are fully justified and consistent in all iterations.

Table 2: Importance degrees of SWOT groups.

\begin{tabular}{lllllll}
\hline & $W_{j}^{\prime \prime 1}$ & $W_{j}^{\prime \prime 2}$ & $W_{j}^{\prime \prime 3}$ & $W_{j}^{\prime \prime 4}$ & $W_{j}^{\prime \prime 5}$ & $W_{j}$ \\
\hline$S$ & 0.2173 & 0.2437 & 0.2689 & 0.2035 & 0.3106 & 0.2459 \\
$W$ & 0.3545 & 0.2437 & 0.2689 & 0.1912 & 0.2535 & 0.2572 \\
0 & 0.2508 & 0.2563 & 0.2195 & 0.2937 & 0.2070 & 0.2436 \\
$T$ & 0.1775 & 0.2563 & 0.2427 & 0.3116 & 0.2289 & 0.2394 \\
$\rho$ & 1.00 & 1.00 & 1.00 & 0.80 & 1.00 & \\
\hline
\end{tabular}

The overall results obtained by using equations (11)-(12), however, show that the Weaknesses Group is assigned the highest priority.

The importance degrees for the factors from the Strengths Group are determined by using Eqs. (1)-(12), and the results are presented in Table 3 . The equations are used to determine the further results.

The importance degrees show that the most significant factor from this group is $S_{5}-$ Several airfields that could become usable for low-budget air companies by making a small investment (Table 3 ).

Table 3: Importance degrees of the Strengths Group.

\begin{tabular}{lllllll}
\hline & $W^{\prime \prime 1}$ & $W_{j}^{\prime \prime 2}$ & $W_{j}^{\prime \prime 3}$ & $W_{j}^{\prime \prime 4}$ & $W_{j}{ }_{j}$ & $W_{j}$ \\
\hline$S_{1}$ & 0.1193 & 0.2241 & 0.2253 & 0.2881 & 0.1455 & 0.1907 \\
$S_{2}$ & 0.2268 & 0.1793 & 0.1840 & 0.1659 & 0.1455 & 0.1784 \\
$S_{3}^{3}$ & 0.1847 & 0.1793 & 0.2034 & 0.1659 & 0.1981 & 0.1858 \\
$S_{4}$ & 0.1351 & 0.1982 & 0.2034 & 0.2191 & 0.2426 & 0.1960 \\
$S_{5}$ & 0.3341 & 0.2191 & 0.1840 & 0.1610 & 0.2683 & 0.2254 \\
$\rho$ & 0.80 & 1.00 & 0.90 & 1.00 & 1.00 & \\
\hline
\end{tabular}

The results obtained for the Weaknesses Group are presented in Table 4. The highest priority in this group is assigned to factor $W_{1}$, which is connected to disrespect for environmental protection measures in protected nature areas and neglecting state-protected structures and monuments.

Table 4: Importance degrees of the Weaknesses Group.

\begin{tabular}{lllllll}
\hline & $W_{j}^{\prime \prime 1}$ & $W_{j}^{\prime 2}$ & $W_{j}^{\prime \prime 3}$ & $W_{j}^{\prime \prime 4}$ & $W_{j}{ }_{j}$ & $W_{j}$ \\
\hline$W_{1}$ & 0.1811 & 0.2699 & 0.2122 & 0.2818 & 0.2570 & 0.2372 \\
$W^{2}$ & 0.1543 & 0.2116 & 0.1919 & 0.1571 & 0.2098 & 0.1832 \\
$W^{3}$ & 0.2053 & 0.2019 & 0.1919 & 0.1813 & 0.1898 & 0.1939 \\
$W^{4}$ & 0.2597 & 0.1774 & 0.1919 & 0.2129 & 0.1717 & 0.2004 \\
$W_{5}$ & 0.1995 & 0.1392 & 0.2122 & 0.1669 & 0.1717 & 0.1760 \\
$\rho$ & 0.70 & 0.95 & 0.90 & 1.00 & 1.00 & \\
\hline
\end{tabular}


G. Popović, D. Stanujkić, P. Mimović, G. Milovanović, D. Karabašević, P. Brzaković, A. Brzaković, An integrated SWOT ...

Table 5 shows the results of evaluating factors from the Opportunities Group. In this case, the most influential factor is $\mathrm{O}_{4}$ - Dynamic growth and development of air transport and reaching new destinations.

Table 5: Importance degrees of the Opportunities Group.

\begin{tabular}{lllllll}
\hline & $W_{j}^{\prime \prime 1}$ & $w_{j}^{\prime \prime 2}$ & $w_{j}^{\prime \prime 3}$ & $W_{j}^{\prime \prime 4}$ & $W_{j}^{\prime \prime 5}$ & $W_{j}$ \\
\hline $0_{1}$ & 0.1559 & 0.2554 & 0.2164 & 0.1874 & 0.1759 & 0.1953 \\
$0_{2}$ & 0.1337 & 0.2004 & 0.2164 & 0.2294 & 0.1945 & 0.1916 \\
$0_{3}^{3}$ & 0.2013 & 0.1813 & 0.1767 & 0.1621 & 0.1759 & 0.1790 \\
$0_{4}$ & 0.2970 & 0.1906 & 0.1953 & 0.2211 & 0.2155 & 0.2209 \\
$\rho_{5}$ & 0.2122 & 0.1724 & 0.1953 & 0.2000 & 0.2382 & 0.2025 \\
\hline
\end{tabular}

Table 6 shows the local importance degrees for the Threats Group. It shows that the factor with the highest weight is $T_{4}$ - Lack of management and coordination reforms in developing tourism in Serbia.

Table 6: Importance degrees of the Threats Group.

\begin{tabular}{ccccccc}
\hline & $W_{j}^{\prime \prime \prime}$ & $W_{j}^{\prime \prime 2}$ & $W_{j}^{\prime \prime 3}$ & $W_{j}^{\prime \prime 4}$ & $W_{j}^{\prime \prime 5}$ & $W_{j}$ \\
\hline$T_{1}$ & 0.2155 & 0.2588 & 0.1659 & 0.1778 & 0.2035 & 0.2018 \\
$T_{2}$ & 0.1518 & 0.1898 & 0.2032 & 0.2349 & 0.2249 & 0.1986 \\
$T_{3}$ & 0.1994 & 0.1898 & 0.2032 & 0.1918 & 0.2035 & 0.1975 \\
$T_{4}$ & 0.2538 & 0.1898 & 0.2032 & 0.2215 & 0.1841 & 0.2090 \\
$T_{5}$ & 0.1795 & 0.1717 & 0.2246 & 0.1739 & 0.1841 & 0.1858 \\
$\rho$ & 0.70 & 1.00 & 1.00 & 0.90 & 0.94 & \\
\hline
\end{tabular}

The factor priority within the groups and the overall factor priorities are presented in Table 7.

Table 7: Overall priority scores of SWOT factors.

\begin{tabular}{|c|c|c|c|c|}
\hline SWOT group & Group priority & SWOT factors & Factor priority within group & Overall factor priority \\
\hline \multirow[t]{5}{*}{ S } & \multirow[t]{5}{*}{0.2459} & $S_{1}$ & 0.1907 & 0.0469 \\
\hline & & $\mathrm{S}_{2}$ & 0.1784 & 0.0439 \\
\hline & & $\mathrm{S}_{3}$ & 0.1858 & 0.0457 \\
\hline & & $\mathrm{S}_{4}$ & 0.1960 & 0.0482 \\
\hline & & $S_{5}$ & 0.2254 & 0.0554 \\
\hline \multirow[t]{5}{*}{$\bar{W}$} & \multirow[t]{5}{*}{0.2572} & $W_{1}$ & 0.2372 & 0.0610 \\
\hline & & $W_{2}$ & 0.1832 & 0.0471 \\
\hline & & $W_{3}$ & 0.1939 & 0.0499 \\
\hline & & $W_{4}$ & 0.2004 & 0.0515 \\
\hline & & $W_{5}$ & 0.1760 & 0.0453 \\
\hline \multirow[t]{5}{*}{$\overline{0}$} & \multirow[t]{5}{*}{0.2436} & $0_{1}$ & 0.1953 & 0.0476 \\
\hline & & $\mathrm{O}_{2}$ & 0.1916 & 0.0467 \\
\hline & & $\mathrm{O}_{3}$ & 0.1790 & 0.0436 \\
\hline & & $\mathrm{O}_{4}$ & 0.2209 & 0.0538 \\
\hline & & $\mathrm{O}_{5}$ & 0.2025 & 0.0493 \\
\hline \multirow[t]{5}{*}{$\bar{T}$} & \multirow[t]{5}{*}{0.2394} & $T_{1}$ & 0.2018 & 0.0483 \\
\hline & & $T_{2}$ & 0.1986 & 0.0476 \\
\hline & & $T_{3}$ & 0.1975 & 0.0473 \\
\hline & & $T_{4}$ & 0.2090 & 0.0501 \\
\hline & & $T_{5}$ & 0.1858 & 0.0445 \\
\hline
\end{tabular}


Each of the six strategies considered are evaluated relative to each SWOT factor estimated as the most important in phase one. By multiplying these results by the overall factor priority, the importance degrees of the strategies are defined (Tables $8 \mathrm{a}$ and $8 \mathrm{~b}$ ).

Table 8a: Importance degrees of strategies according to SWOT factors.

\begin{tabular}{|c|c|c|c|c|c|c|c|c|c|c|}
\hline & $S_{1}$ & $\mathrm{~S}_{2}$ & $\mathrm{~S}_{3}$ & $\mathrm{~S}_{4}$ & $S_{5}$ & $W_{1}$ & $W_{2}$ & $W_{3}$ & $W_{4}$ & $W_{5}$ \\
\hline $\mathrm{SO}_{1}$ & 0.1880 & 0.1499 & 0.1491 & 0.1421 & 0.1895 & 0.1187 & 0.1437 & 0.1259 & 0.1470 & 0.1632 \\
\hline $\mathrm{SO}_{2}$ & 0.1874 & 0.1537 & 0.1620 & 0.1599 & 0.1638 & 0.1312 & 0.1600 & 0.1401 & 0.1490 & 0.1739 \\
\hline WO & 0.1427 & 0.1590 & 0.1528 & 0.1522 & 0.1509 & 0.1403 & 0.1598 & 0.1489 & 0.1586 & 0.1601 \\
\hline$W T_{1}$ & 0.1373 & 0.1626 & 0.1635 & 0.1507 & 0.1562 & 0.1598 & 0.1645 & 0.1517 & 0.1620 & 0.1446 \\
\hline$W T_{2}$ & 0.1630 & 0.1705 & 0.1754 & 0.1956 & 0.1615 & 0.1920 & 0.1805 & 0.1791 & 0.1936 & 0.1743 \\
\hline$S T_{1}^{2}$ & 0.1816 & 0.2042 & 0.1971 & 0.1995 & 0.1782 & 0.2580 & 0.1915 & 0.2544 & 0.1898 & 0.1839 \\
\hline
\end{tabular}

Table 8b: Priority scores of strategies according to SWOT factors.

\begin{tabular}{|c|c|c|c|c|c|c|c|c|c|c|}
\hline & $0_{1}$ & $\mathrm{O}_{2}$ & $\mathrm{O}_{3}$ & $\mathrm{O}_{4}$ & $O_{5}$ & $T_{1}$ & $T_{2}$ & $T_{3}$ & $T_{4}$ & $T_{5}$ \\
\hline $\mathrm{SO}_{1}$ & 0.1820 & 0.1744 & 0.1332 & 0.2083 & 0.1462 & 0.1690 & 0.1551 & 0.1528 & 0.1646 & 0.1890 \\
\hline $\mathrm{SO}_{2}$ & 0.1907 & 0.1435 & 0.1679 & 0.1830 & 0.1517 & 0.1635 & 0.1713 & 0.1397 & 0.1519 & 0.1585 \\
\hline wo & 0.1725 & 0.1434 & 0.1945 & 0.1469 & 0.1516 & 0.1689 & 0.1738 & 0.1636 & 0.1672 & 0.1584 \\
\hline$W T_{1}$ & 0.1517 & 0.1728 & 0.1712 & 0.1370 & 0.1616 & 0.1516 & 0.1634 & 0.1548 & 0.1583 & 0.1673 \\
\hline$W T_{2}$ & 0.1500 & 0.1876 & 0.1524 & 0.1553 & 0.1747 & 0.1748 & 0.1673 & 0.1771 & 0.1702 & 0.1611 \\
\hline$S T_{1}^{2}$ & 0.1531 & 0.1782 & 0.1809 & 0.1695 & 0.2141 & 0.1722 & 0.1691 & 0.2120 & 0.1877 & 0.1657 \\
\hline
\end{tabular}

Table 9 shows the overall priority of the strategies considered. Figure 2 shows the final ranking order of the strategies evaluated.

Table 9: Overall priority of the strategies.

\begin{tabular}{llcc}
\hline Strategy & & Overall priority & Rank \\
\hline $\mathrm{SO}_{1}$ & Improving tourist and traffic infrastructure in Serbia & 0.1553 & 4 \\
$\mathrm{SO}_{2}$ & Improving tourist products and services in Serbia & 0.1556 & 3 \\
$\mathrm{WO}_{1}$ & Improvement human resources and the labor market & 0.1537 & 5 \\
$\mathrm{WT}_{1}$ & Networking with other sectors & 0.1528 & 6 \\
$\mathrm{WT}_{2}$ & Improving the national tourism marketing system & 0.1685 & 2 \\
$\mathrm{ST}_{1}$ & Improving the organization, management, and enhancement of tourism development & 0.1879 & 1 \\
\hline
\end{tabular}

Figure 2 shows that the highest overall priority is assigned to strategy $S T_{1}$ - Improving the organization, management, and enhancement of tourism development. This result is fully justified, especially when taking into account the most influential factor from the Threats Group, $T_{4}$ - Lack of management and coordination reforms in developing tourism in Serbia. There is a need to seriously improve tourism management, modernize tourism organizations, and renovate tourism infrastructure. Based on the results, the strategy that should be implemented last is $W T_{1}-$ Networking with other sectors. This does not mean that this strategy is the least important, but that the appropriate conditions must be created that will allow the coordinated action of all sectors. 


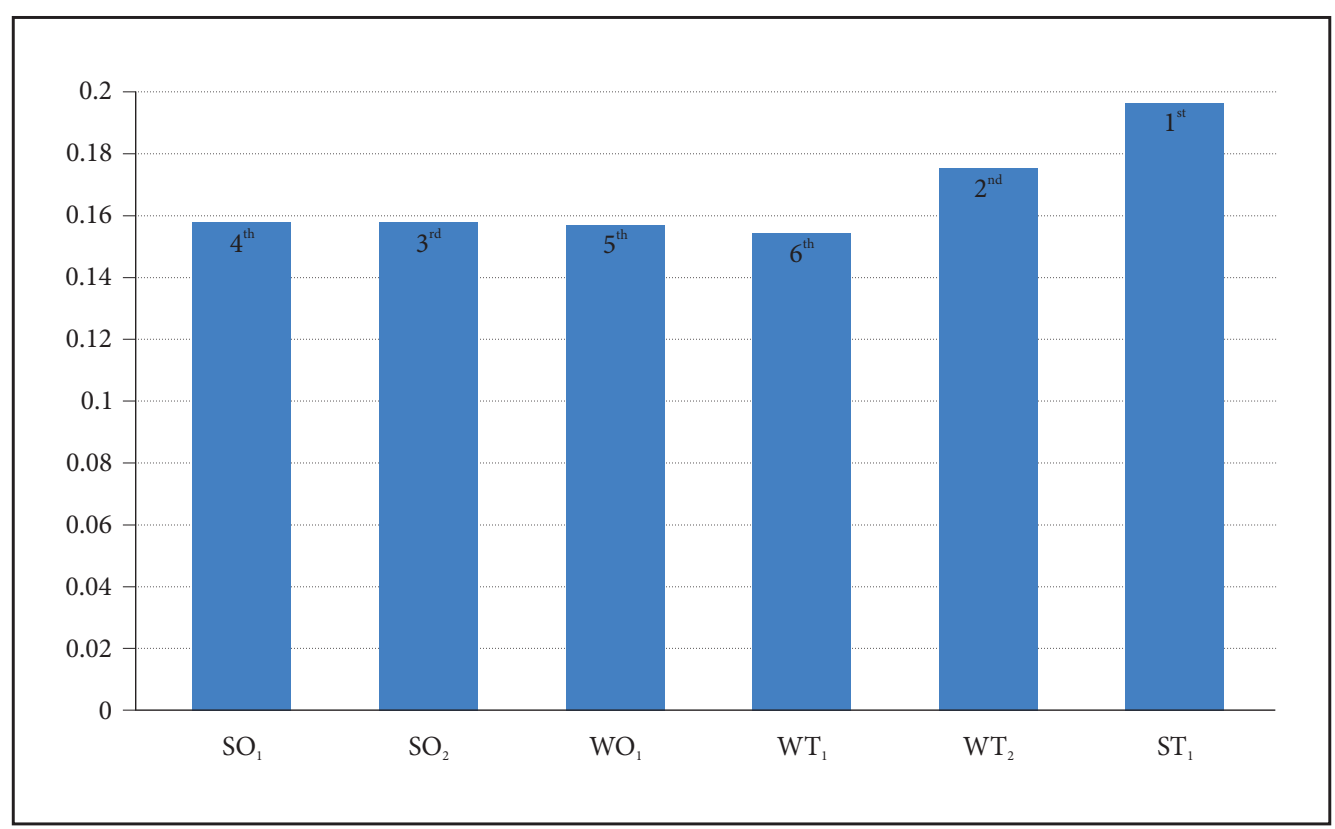

Figure 2: Final ranking order of strategies.

\section{Discussion}

The reason for proposing a model based on the SWOT and PIPRECIA methods is that, although SWOT analysis is a proven strategic tool, it has certain flaws. SWOT analysis has a qualitative nature and cannot reveal the importance of factors or their impact on the final decision (Yüksel and Dagdeviren 2007; Kajanus et al. 2012; Vlados 2019). This is resolved by combining the SWOT technique with extended PIPRECIA. This new integrated model clearly shows the significance of the SWOT factors as well as which of them is the most influential.

Compared to the A'WOT model, which is often used for prioritizing strategies (Kajanus, Kangas and Kurttila 2004; Akbulak and Cengiz 2014; Kişi 2019; Bottero, D’Alpaos and Marello 2020), the proposed integrated model has certain advantages. The proposed approach uses a decision-making procedure adjusted for a group decision environment and, although extended PIPRECIA is somewhat complicated, it is easy for respondents to understand.

The proposed model has certain benefits relative to the SWARA method, which is also used in combination with SWOT analysis (Popović, Milovanović and Stanujkić 2018). Although the SWARA method, which represents the core of extended PIPRECIA, has a computational procedure that is much easier, it is not suitable for a group decision environment. This is mainly because the SWARA method requires presorting of the criteria considered, and so all DMs can give their ranking orders, which complicates obtaining the results. Extended PIPRECIA does not involve pre-sorting the criteria in the evaluation procedure, which facilitates gathering and calculating the results from a greater number of DMs. Furthermore, extended PIPRECIA predicts verifying the reliability of the results, which is not the case with the SWARA method.

The proposed model was applied to a case study examining the advantages and disadvantages of tourism in Serbia. The SWOT analysis used in this work is taken from the Tourism Development Strategy of the Republic of Serbia 2016-2025 (2016). Because this analysis contains many factors, the evaluation was conducted in two phases. In phase one, the five most important factors from each SWOT group were determined by using the PIPRECIA method and group decision-making. In phase two, the final priority scores of the 
factors and the final ranking of the strategies relative to the given factors were calculated. The evaluation process in both phases was entrusted to tourism experts, who are familiar with the tourism situation in Serbia. The strategy assigned priority under current conditions is strategy $S T_{1}$-Improving the organization, management, and enhancement of tourism development. This is justified because, although Serbia has great tourism potential, it should improve organization and management in tourism and improve its position on the world tourism market.

Comparing the results with those obtained by other researchers shows a certain disparity among countries regarding the priority of strategies for tourism development. For example, Ajmera (2017) inferred that the $S O$ strategy is the best choice for medical tourism development in India. Büyüközkan, Mukul and Kongar (2020) also emphasize the SO strategy for health tourism development in Istanbul, Turkey. Abadi et al. (2018) defined the WO strategy as the best for medical tourism in Iran. For ecotourism in Djerdap National Park in Serbia, the most important strategy is ST, as in our case (Arsić, Nikolić and Živković 2017). The fact that these studies focus on different types of tourism does not influence the conclusion that the methodology used does not affect the result but depends on the tourism situation in a given country. As stated, there are many issues to resolve in Serbian tourism, which leads to the result presented here.

In this particular case, decision-making is performed by five DMs. By involving a greater number of DMs from different tourism structures, the results are more reliable. It would be desirable to perform a new SWOT analysis taking into account the current situation caused by the COVID-19 pandemic. A disadvantage of the proposed model is the use of precise numbers. Decision-making is conducted in an environment characterized by uncertainty and vagueness, and so it is important to include this incertitude in the decision process. By introducing fuzzy sets (Atanassov 1986), gray systems (Deng 1982), or neutrosophic numbers (Smarandache 2005), the reliability of the analysis and the decisions will increase because the vagueness and uncertainty of the environment will be better included.

\section{Conclusion}

Decision-making in tourism and other research areas requires a methodical approach to achieve appropriate decisions. Mathematical tools such as MCDM methods are often used to increase the level of certainty of the decisions. As stated previously, this article proposes applying an integrated model based on SWOT analysis and extended PIPRECIA as a decision-making aid for strategic planning in tourism. The possibilities of the integrated model are tested using a case study to identify the key determinants for tourism development in Serbia. The results are appropriate and in line with current positions on tourism in Serbia.

By introducing the new integrated SWOT - extended PIPRECIA model, the theoretical and practical dimensions of MCDM are enhanced and the possibilities of its application are clearly outlined. The crucial advantages of the model lie in its suitability for application in a group-decision environment, its relatively simple and understandable procedure, and the systematic approach for DMs in identifying and implementing strategies for tourism development. Applying the integrated model to tourism in Serbia offers a completely different perspective from one based only on SWOT analysis. An obsolete and generalized SWOT analysis, the small number of DMs involved in the evaluation, and the use of precise numbers are the main limitations of this article.

As the literature review shows, the proposed model has not been widely explored and discussed yet, and so the directions for future research lie in examining this model in various research areas. Future research should also address integrating the model with rough, fuzzy, intuitionistic, or gray numbers. This would acknowledge the uncertainty that is always part of the decision process at a higher level.

\section{References}

Abadi, F. A., Sahebi, I. G., Arab, A., Alavi, A., Karachi, H. 2018: Application of best-worst method in evaluation of medical tourism development strategy. Decision Science Letters 7-1. DOI: https://doi.org/ $10.5267 /$ j.dsl.2017.4.002

Ajmera, P. 2017: Ranking the strategies for Indian medical tourism sector through the integration of SWOT analysis and TOPSIS method. International Journal of Health Care Quality Assurance 30-8. DOI: https://doi.org/10.1108/IJHCQA-05-2016-0073 
Akbulak, C., Cengiz, T. 2014: Determining ecotourism strategies using A’WOT hybrid method: Case study of Troia Historical National Park, Çanakkale, Turkey. International Journal of Sustainable Development and World Ecology 21-4. DOI: https://doi.org/10.1080/13504509.2014.903383

Akincilar, A., Dagdeviren, M. 2014: A hybrid multi-criteria decision making model to evaluate hotel websites. International Journal of Hospitality Management 36. DOI: https://doi.org/10.1016/j.ijhm.2013.10.002

Aksoy, S., Ozbuk, M. Y. 2017: Multiple criteria decision making in hotel location: does it relate to postpurchase consumer evaluations? Tourism Management Perspectives 22. DOI: https://doi.org/10.1016/ j.tmp.2017.02.001

Aliani, H., Kafaky, S. B., Saffari, A., Monavari, S. M. 2017: Land evaluation for ecotourism development An integrated approach based on FUZZY, WLC and ANP methods. International Journal of Environmental Science and Technology 14-9. DOI: https://doi.org/10.1007/s13762-017-1291-5

Armenski, T., Dwyer, L., Pavluković, V. 2018: Destination competitiveness: Public and private sector tourism management in Serbia. Journal of Travel Research 57-3. DOI: https://doi.org/10.1177/0047287517692445

Arsić, S., Nikolić, D., Živković, Ž. 2017: Hybrid SWOT-ANP-FANP model for prioritization strategies of sustainable development of ecotourism in National Park Djerdap, Serbia. Forest Policy and Economics 80. DOI: https://doi.org/10.1016/j.forpol.2017.02.003

Atanassov, K. T. 1986: Intuitionistic fuzzy sets. Fuzzy Sets and Systems 20-1. DOI: https://doi.org/10.1016/ S0165-0114(86)80034-3

Blešić, I., Pivac, T., Đorđević, J., Stamenković, I., Janićević, S. 2014: Cultural events as part of cultural tourism development. Case study: Sombor and Apatin (Serbia). Acta geographica Slovenica 54-2. DOI: https://doi.org/10.3986/AGS54406

Bottero, M., D’Alpaos, C., Marello, A. 2020: An application of the a'WOT analysis for the management of cultural heritage assets: The case of the historical farmhouses in the Aglié Castle (Turin). Sustainability 12-3. DOI: https://doi.org/10.3390/su12031071

Božić, S., Tomić, N. 2016: Developing the cultural route evaluation model (CREM) and its application on the Trail of Roman Emperors, Serbia. Tourism Management Perspectives 17. DOI: https://doi.org/ 10.1016/j.tmp.2015.11.002

Büyüközkan, G., Mukul, E., Kongar, E. 2021: Health tourism strategy selection via SWOT analysis and integrated hesitant fuzzy linguistic AHP-MABAC approach. Socio-Economic Planning Sciences 74. DOI: https://doi.org/10.1016/j.seps.2020.100929

Cetin, M. 2015: Evaluation of the sustainable tourism potential of a protected area for landscape planning: A case study of the ancient city of Pompeipolis in Kastamonu. International Journal of Sustainable Development and World Ecology 22-6. DOI: https://doi.org/10.1080/13504509.2015.1081651

Cetin, M., Zeren, I., Sevik, H., Cakir, C., Akpinar, H. 2018: A study on the determination of the natural park's sustainable tourism potential. Environmental Monitoring and Assessment 190. DOI: https://doi.org/ 10.1007/s10661-018-6534-5

Cheng, Q., Su, B., Tan, J. 2013: Developing an evaluation index system for low-carbon tourist attractions in China - a case study examining the Xixi wetland. Tourism Management 36. DOI: https://doi.org/ 10.1016/j.tourman.2012.10.019

Chou, T. Y., Hsu, C. L., Chen, M. C. 2008: A fuzzy multi-criteria decision model for international tourist hotels location selection. International Journal of Hospitality Management 27-2. DOI: https://doi.org/ 10.1016/j.ijhm.2007.07.029

Đalić, I., Ateljević, J., Stević, Ž., Terzić, S. 2020a: An integrated SWOT - fuzzy PIPRECIA model for analysis of competitiveness in order to improve logistics performances. Facta Universitatis, Series: Mechanical Engineering 18-3. DOI: https://doi.org/10.22190/FUME200325029D

Đalić, I., Stević, Ž., Karamasa, C., Puška, A. 2020b: A novel integrated fuzzy PIPRECIA - interval rough saw model: green supplier selection. Decision Making: Applications in Management and Engineering 3-1. DOI: https://doi.org/10.31181/dmame2003114d

Demir, S., Esbah, H., Akgün, A. A. 2016: Quantitative SWOT analysis for prioritizing ecotourism - planning decisions in protected areas: Igneada case. International Journal of Sustainable Development and World Ecology 23-5. DOI: https://doi.org/10.1080/13504509.2015.1136709

Deng, J. L. 1982: Control problems of grey systems. Systems and Control Letters 1-5. DOI: https://doi.org/ 10.1016/S0167-6911(82)80025-X 
Dimitrovski, D. D., Todorović, A. T., Valjarević, A. D. 2012: Rural tourism and regional development: case study of development of rural tourism in the region of Gruža, Serbia. Procedia Environmental Sciences 14. DOI: https://doi.org/10.1016/j.proenv.2012.03.028

Dragićević, V., Besermenji, S., Pivac, T., Ivkov-Džigurski, A., Košić, K. 2013: Evaluation of tourist attractiveness and museum management in Sombor and Apatin (Serbia). Acta geographica Slovenica 53-2. DOI: https://doi.org/10.3986/AGS53405

Dragićević, V., Jovičić, D., Blešić, I., Stankov, U., Bošković, D. 2012: Business tourism destination competitiveness: A case of Vojvodina Province (Serbia). Economic Research-Ekonomska Istraživanja 25-2. DOI: https://doi.org/10.1080/1331677X.2012.11517510

Gavade, R. K. 2014: Multi-Criteria Decision Making: An overview of different selection problems and methods. International Journal of Computer Science and Information Technologies 5-4.

Ghazinoory, S., Abdi, M., Azadegan-Mehr, M. 2011: SWOT methodology: A state-of-the-art review for the past, a framework for the future. Journal of Business Economics and Management 12-1. DOI: https://doi.org/10.3846/16111699.2011.555358

Gómez-Vega, M., Picazo-Tadeo, A. J. 2019: Ranking world tourist destinations with a composite indicator of competitiveness: To weigh or not to weigh? Tourism Management 72. DOI: https://doi.org/10.1016/ j.tourman.2018.11.006

Gürel, E., Tat, M. 2017: SWOT analysis: A theoretical review. Journal of International Social Research 10-51. DOI: https://doi.org/10.17719/jisr.2017.1832

Helms, M. M., Nixon, J. 2010: Exploring SWOT analysis - where are we now? A review of academic research from the last decade. Journal of Strategy and Management 3-3. DOI: https://doi.org/10.1108/ 17554251011064837

Hill, T., Westbrook, R. 1997: SWOT analysis: it's time for a product recall. Long Range Planning 30-1. DOI: https://doi.org/10.1016/S0024-6301(96)00095-7

Hu, Y. C. 2009: Fuzzy multiple-criteria decision making in the determination of critical criteria for assessing service quality of travel websites. Expert Systems with Applications 36-3. DOI: https://doi.org/10.1016/ j.eswa.2008.07.046

Huang, J. H., Peng, K. H. 2012: Fuzzy Rasch model in TOPSIS: A new approach for generating fuzzy numbers to assess the competitiveness of the tourism industries in Asian countries. Tourism Management 33-2. DOI: https://doi.org/10.1016/j.tourman.2011.05.006

Jiskani, I. M., Shah, S. A. A., Qingxiang, C., Zhou, W., Lu, X. 2020: A multi-criteria based SWOT analysis of sustainable planning for mining and mineral industry in Pakistan. Arabian Journal of Geosciences 13. DOI: https://doi.org/10.1007/s12517-020-06090-3

Kajanus, M., Kangas, J., Kurttila, M. 2004: The use of value focused thinking and the A'WOT hybrid method in tourism management. Tourism Management 25-4. DOI: https://doi.org/10.1016/S0261-5177(03)00120-1

Kajanus, M., Leskinen, P., Kurttila, M., Kangas, J. 2012: Making use of MCDS methods in SWOT analysis - Lessons learnt in strategic natural resources management. Forest Policy and Economics 20. DOI: https://doi.org/10.1016/j.forpol.2012.03.005

Karabasevic, D., Popovic, G., Stanujkic, D., Maksimovic, M., Sava, C. 2019: An approach for hotel type selection based on the single-valued intuitionistic fuzzy numbers. International Review 2019-1,2.

Keršuliene, V., Zavadskas, E. K., Turskis, Z. 2010: Selection of rational dispute resolution method by applying new stepwise weight assessment ratio analysis (SWARA). Journal of Business Economics and Management 11-2. DOI: https://doi.org/10.3846/jbem.2010.12

Khan, M. I. 2018: Evaluating the strategies of compressed natural gas industry using an integrated SWOT and MCDM approach. Journal of Cleaner Production 172. DOI: https://doi.org/10.1016/j.jclepro.2017.10.231

Kişi, N. 2019: A strategic approach to sustainable tourism development using the A'WOT hybrid method: A case study of Zonguldak, Turkey. Sustainability 11-4. DOI: https://doi.org/10.3390/su11040964

Košić, K., Pivac, T., Romelić, J., Lazić, L., Stojanović, V. 2011: Characteristics of thermal-mineral waters in Backa region (Vojvodina) and their exploitation in spa tourism. Renewable and Sustainable Energy Reviews 15-1. DOI: https://doi.org/10.1016/j.rser.2010.09.004

Kurttila, M., Pesonen, M., Kangas, J., Kajanus, M. 2000: Utilizing the analytic hierarchy process (AHP) in SWOT analysis - A hybrid method and its application to a forest-certification case. Forest Policy and Economics 1-1. DOI: https://doi.org/10.1016/S1389-9341(99)00004-0 
Liu, C. H., Tzeng, G. H., Lee, M. H. 2012: Improving tourism policy implementation - the use of hybrid MCDM models. Tourism Management 33-2. DOI: https://doi.org/10.1016/j.tourman.2011.05.002

Memiş, S., Demir, E., Karamaşa, Ç., Korucuk, S. 2020: Prioritization of road transportation risks: An application in Giresun province. Operational Research in Engineering Sciences: Theory and Applications 3-2.

Michailidou, A. V., Vlachokostas, C., Moussiopoulos, N. 2016: Interactions between climate change and the tourism sector: multiple-criteria decision analysis to assess mitigation and adaptation options in tourism areas. Tourism Management 55. DOI: https://doi.org/10.1016/j.tourman.2016.01.010

Michalena, E., Hills, J., Amat, J. P. 2009: Developing sustainable tourism, using a multicriteria analysis on renewable energy in Mediterranean Islands. Energy for Sustainable Development 13-2. DOI: https://doi.org/ 10.1016/j.esd.2009.06.001

Mimović, P., Kocić, M., Milanović, M. 2012: A'WOT model in selecting the optimal tourism development strategy in Vrnjacka Banja. Teme 36-2.

Morteza, Z., Reza, F. M., Seddiq, M. M., Sharareh, P., Jamal, G. 2016: Selection of the optimal tourism site using the ANP and fuzzy TOPSIS in the framework of Integrated Coastal Zone Management: A case of Qeshm Island. Ocean and Coastal Management 130. DOI: https://doi.org/10.1016/j.ocecoaman.2016.06.012

Mulec, I., Wise, N. 2013: Indicating the competitiveness of Serbia’s Vojvodina Region as an emerging tourism destination. Tourism Management Perspectives 8. DOI: https://doi.org/10.1016/j.tmp.2013.07.001

Nikolić, Đ., Spasić, J., Živković, Ž., Đorđević, P., Mihajlović, I., Kangas, J. 2015: SWOT-AHP model for prioritization of strategies of the resort Stara Planina. Serbian Journal of Management 10-2.

Pavluković, V., Stankov, U., Arsenović, D. 2020: Social impacts of music festivals: A comparative study of Sziget (Hungary) and Exit (Serbia). Acta geographica Slovenica 60-1. DOI: https://doi.org/10.3986/AGS.6514

Petrović, M. D., Vujko, A., Gajić, T., Vuković, D. B., Radovanović, M., Jovanović, J. M., Vuković, N. 2018: Tourism as an approach to sustainable rural development in post-socialist countries: A comparative study of Serbia and Slovenia. Sustainability 10-1. DOI: https://doi.org/10.3390/su10010054

Popović, G., Đorđević, B., Milanović, D. 2019: Multiple criteria approach in the mining method selection. Industrija 47-4. DOI: https://doi.org/10.5937/industrija47-24128

Popović, G., Mihajlović, D. 2018: An MCDM approach to tourism projects evaluation: The Upper Danube Basin case. Modern Management Tools and Economy of Tourism Sector in Present Era, 3rd International Thematic Monograph - Thematic Proceedings. Ohrid. DOI: https://doi.org/10.31410/ tmt.2018.129

Popović, G., Milovanović, G., Stanujkić, D. 2018: Prioritization of strategies for tourism development by applying a SWOT-SWARA analysis: The case of Sokobanja Spa. Teme 42-3. DOI: https://doi.org/10.22190/ TEME1803999P

Popovic, G., Stanujkic, D., Karabasevic, D. 2019: A framework for the evaluation of hotel property development projects. International Journal of Strategic Property Management 23-2. DOI: https://doi.org/10.3846/ ijspm.2019.7435

Popovic, G., Stanujkic, D., Karabasevic, D., Maksimovic, M., Sava, C. 2019: Multiple criteria approach in the ranking of the sustainable indicators for cultural heritage sites. Quaestus 14.

Puška, A., Stojanović, I., Maksimović, A. 2019: Evaluation of sustainable rural tourism potential in Brcko district of Bosnia and Herzegovina using multi-criteria analysis. Operational Research in Engineering Sciences: Theory and Applications 2-2. DOI: https://doi.org/10.31181/oresta190261p

Reihanian, A., Mahmood, N. Z. B., Kahrom, E., Hin, T. W. 2012: Sustainable tourism development strategy by SWOT analysis: Boujagh National Park, Iran. Tourism Management Perspectives 4. DOI: https://doi.org/10.1016/j.tmp.2012.08.005

Rozman, Č., Potočnik, M., Pažek, K., Borec, A., Majkovič, D., Bohanec, M. 2009: A multi-criteria assessment of tourist farm service quality. Tourism Management 30-5. DOI: https://doi.org/10.1016/ j.tourman.2008.11.008

Saaty, T. L. 1980: The analytic hierarchy process. New York.

Sariisik, M., Turkay, O., Akova, O. 2011: How to manage yacht tourism in Turkey: A SWOT analysis and related strategies. Procedia - Social and Behavioral Sciences 24. DOI: https://doi.org/10.1016/ j.sbspro.2011.09.041

Smarandache, F. 2005: Neutrosophic set - a generalization of the intuitionistic fuzzy set. International Journal of Pure and Applied Mathematics 24-3. 
Stanujkic, D., Karabasevic, D., Sava, C. 2018: An application of the PIPRECIA and WS PLP methods for evaluating website quality in hotel industry. Quaestus 12.

Stanujkic, D., Karabasevic, D., Zavadskas, E. K., Smarandache, F., Cavallaro, F. 2019: An approach to determining customer satisfaction in traditional Serbian restaurants. Entrepreneurship and Sustainability Issues 6-3. DOI: https://doi.org/10.9770/jesi.2019.6.3(5)

Stanujkic, D., Zavadskas, E. K., Karabasevic, D., Smarandache, F., Turskis, Z. 2017a: The use of the pivot pairwise relative criteria importance assessment method for determining the weights of criteria. Romanian Journal of Economic Forecasting 20-4.

Stanujkic, D., Zavadskas, E. K., Karabasevic, D., Urosevic, S., Maksimovic, M. 2017b: An approach for evaluating website quality in hotel industry based on triangular intuitionistic fuzzy numbers. Informatica 28-4.

Stanujkic, D., Zavadskas, E. K., Liu, S., Karabasevic, D., Popovic, G. 2017c: Improved OCRA method based on the use of interval grey numbers. Journal of Grey System 29-4.

Stanujkic, D., Zavadskas, E. K., Tamošaitienè, J. 2015: An approach to measuring website quality in the rural tourism industry based on Atanassov intuitionistic fuzzy sets. E+M Ekonomie a Management 18-4. DOI: https://doi.org/10.15240/tul/001/2015-4-013

Stević, Ž., Stjepanović, Ž., Božičković, Z., Das, D. K., Stanujkić, D. 2018: Assessment of conditions for implementing information technology in a warehouse system: A novel fuzzy PIPRECIA method. Symmetry 10-11. DOI: https://doi.org/10.3390/sym10110586

Stojčić, M., Zavadskas, E. K., Pamučar, D., Stević, Ž., Mardani, A. 2019: Application of MCDM methods in sustainability engineering: A literature review 2008-2018. Symmetry 11-3. DOI: https://doi.org/ $10.3390 /$ sym 11030350

Tourism Development Strategy of the Republic of Serbia 2016-2025. Ministry of Trade, Tourism and Telecommunications of the Republic of Serbia, Belgrade, 2016.

Todorović, M., Bjeljac, Ž. 2009: Rural tourism in Serbia as a concept of development in undeveloped regions. Acta geographica Slovenica 49-2. DOI: https://doi.org/10.3986/AGS49208

Tseng, M. L. 2011: Using hybrid MCDM to evaluate the service quality expectation in linguistic preference. Applied Soft Computing 11-8. DOI: https://doi.org/10.1016/j.asoc.2011.08.011

Vasiljević, D. A., Marković, S. B., Hose, T. A., Smalley, I., O’Hara-Dhand, K., Basarin, B., Lukić, T., Vujičić, M. D. 2011: Loess towards (geo) tourism - proposed application on loess in Vojvodina region (north Serbia). Acta geographica Slovenica 51-2. DOI: https://doi.org/10.3986/AGS51305

Vesković, S., Milinković, S., Abramović, B., Ljubaj, I. 2020: Determining criteria significance in selecting reach stackers by applying the fuzzy PIPRECIA method. Operational Research in Engineering Sciences: Theory and Applications 3-1.

Vlados, C. 2019: On a correlative and evolutionary SWOT analysis. Journal of Strategy and Management 12-3. DOI: https://doi.org/10.1108/JSMA-02-2019-0026

Vujičić, M. D., Vasiljević, D. A., Marković, S. B., Hose, T. A., Lukić, T., Hadžić, O., Janićević, S. 2011: Preliminary geosite assessment model (GAM) and its application on Fruška Gora Mountain, potential geotourism destination of Serbia. Acta geographica Slovenica 51-2. DOI: https://doi.org/10.3986/AGS51303

Vujko, A., Plavša, J. 2014: Evaluation of Fruška Gora National Park (Serbia) for sport and recreational tourism. Acta geographica Slovenica 54-2. DOI: https://doi.org/10.3986/AGS54206

Wu, C., Wang, R. 2014: Evaluating Chinese tourist's service quality criteria under uncertainty. International Review of Management and Business Research 3-2.

Wu, W. W. 2011: Beyond travel and tourism competitiveness ranking using DEA, GST, ANN and Borda count. Expert Systems with Applications 38-10. DOI: https://doi.org/10.1016/j.eswa.2011.04.096

Yüksel, İ., Dag` deviren, M. 2007: Using the analytic network process (ANP) in a SWOT analysis - a case study for a textile firm. Information Sciences 177-16. DOI: https://doi.org/10.1016/j.ins.2007.01.001

Zavadskas, E. K., Turskis, Z. 2011: Multiple criteria decision making (MCDM) methods in economics: An overview. Technological and Economic Development of Economy 17-2. DOI: https://doi.org/10.3846/ 20294913.2011.593291

Zavadskas, E. K., Turskis, Z., Kildienè, S. 2014: State of art surveys of overviews on MCDM/MADM methods. Technological and Economic Development of Economy 20-1. DOI: https:/doi.org/10.3846/ 20294913.2014.892037 
Zhang, H., Gu, C. L., Gu, L. W., Zhang, Y. 2011: The evaluation of tourism destination competitiveness by TOPSIS and information entropy - A case in the Yangtze River Delta of China. Tourism Management 32-2. DOI: https://doi.org/10.1016/j.tourman.2010.02.007

Zoraghi, N., Amiri, M., Talebi, G., Zowghi, M. 2013: A fuzzy MCDM model with objective and subjective weights for evaluating service quality in hotel industries. Journal of Industrial Engineering International 9. DOI: https://doi.org/10.1186/2251-712X-9-38 